Volume 2 Nomor 2, Juni - November 2020, halaman 177 - 192

Tersedia Daring pada https://journal.unwira.ac.id/index.php/ASIMTOT

\title{
KEMAMPUAN PEMAHAMAN KONSEP ALJABAR PADA PEMBELAJARAN BERBASIS VIRTUAL MANIPULATIVE
}

\author{
Florianus Aloysius $\mathrm{Nay}^{1}$, Osniman Paulina Maure ${ }^{2}$ \\ ${ }^{1,2}$ Universitas San Pedro \\ Olandnay21juni@gmail.com ${ }^{1}$, Osnimanpaulinamaure@gmail.com ${ }^{2}$
}

\begin{abstract}
Abstrak: Penelitian ini bertujuan untuk mendeskripsikan pemahaman konsep siswa setelah mengikuti pembelajaran matematika pada topik aljabar menggunakan media pembelajaran virtual manipulative. Penelitian ini menggunakan pendekatan kualitatif deskiptif. Penelitian ini dilaksanakan di SMP Santo Aloysius Turi Sleman Yogyakarta. Subjek pada penelitian ini terdiri atas siswa kelas $\mathrm{VII}_{\mathrm{A}}$ dengan jumlah 24 siswa dan diambil 3 siswa untuk diwawancarai. Subjek dikelompokkan dalam kategori jawaban yang rendah, sedang, dan tinggi. Teknik pengumpulan data pada penelitian ini menggunakan tes tertulis dan wawancara. Hasil penelitian menunjukkan bahwa siswa dengan kemampuan rendah memenuhi indikator pemahaman konsep yaitu menyajikan konsep dalam berbagai bentuk representasi matematis, dan menggunakan, memanfaatkan, dan memilih prosedur atau operasi tertentu dalam menyelesaikan masalah, siswa dengan kemampuan sedang dapat memenuhi indikator pemahaman konsep yaitu menyajikan konsep dalam berbagai bentuk representasi matematis, dan menggunakan, memanfaatkan, dan memilih prosedur atau operasi tertentu dalam menyelesaikan masalah. Siswa dengan kemampuan tinggi memenuhi indikator pemahaman konsep yaitu menyatakan ulang setiap konsep, mengklasifikasikan konsep menurut sifat-sifat tertentu (sesuai dengan konsepnya), menyajikan konsep dalam berbagai bentuk representasi matematis, dan menggunakan, memanfaatkan, dan memilih prosedur atau operasi tertentu dalam menyelesaikan masalah.
\end{abstract}

Kata Kunci: Aljabar, Virtual Manipulative, Pemahaman Konsep

Abstract: This study aims to describe students' understanding of concepts after participating in mathematics learning on the topic of algebra using manipulative virtual learning media. This study uses a descriptive qualitative approach. This research was conducted at SMP Santo Aloysius Turi Sleman Yogyakarta. The subjects in this study consisted of 24 students of class VII ${ }_{A}$ and 3 students were taken to be interviewed. Subjects were grouped into low, medium, and high answer categories. Data collection techniques in this study used written tests and interviews. The results showed that students with low abilities met the indicators of concept understanding, namely presenting concepts in various forms of mathematical representations, and using, utilizing, and selecting certain procedures or operations in solving problems, students with moderate ability could meet the conceptual understanding indicators, namely presenting concepts in various form of mathematical representation, and using, utilizing, and selecting certain procedures or operations in solving problems. Students with high abilities meet the indicators of concept understanding, namely restating each concept, classifying concepts according to certain properties (according to the concept), presenting concepts in various forms of mathematical representation, and using, utilizing, and selecting certain procedures or operations in solving problems.

Keywords: Algebra, Virtual Manipulative, Concept Understanding

Cara Sitasi: Nay, A. F., Maure, P. O. (2020). Kemampuan Pemahaman Konsep Aljabar Pada Pembelajaran Berbasis Virtual Manipulative. Asimtot: Jurnal Kependidikan Matematika, “2”(“2”),"177-192. 


\section{ASIMTOT: JURNAL KEPENDIDIKAN MATEMATIKA}

Volume 2 Nomor 2, Juni - November 2020, halaman 177 - 192

Tersedia Daring pada https://journal.unwira.ac.id/index.php/ASIMTOT

Salah satu landasan penting yang diperlukan dalam menyelesaikan permasalahan matematika maupun permasalahan sehari-hari adalah pemahaman konsep matematika. Dalam pembelajaran matematika, siswa perlu diberikan kesempatan untuk mengkonstruksi konsep matematika. Menurut Duffin \& Simpson (2000), kemampuan pemahaman konsep dapat membantu siswa mengungkapkan kembali konsep yang telah dikomunikasikan kepadanya, menggunakan konsep pada berbagai situasi yang berbeda, dan mengembangkan beberapa akibat dari adanya suatu konsep sehingga siswa mampu menyelesaikan suatu masalah dengan benar.

Menurut NCTM (2000), agar mencapai pemahaman yang bermakna maka pembelajaran matematika harus diarahkan pada pengembangan kemampuan koneksi matematika antar berbagai ide, memahami bagaimana ide-ide matematika saling terkait satu sama lain sehingga terbangun pemahaman menyeluruh, dan menggunakan matematika dalam konteks di luar matematika. Menurut Permendiknas No. 22 Tahun 2006 (Depdiknas, 2006:346), salah satu tujuan matematika pada pendidikan menengah adalah agar siswa memiliki kemampuan memahami konsep matematika, menjelaskan keterkaitan antar konsep, dan mengaplikasikan konsep atau algoritma secara luwes, akurat, efisien, dan tepat dalam pemecahan masalah.

$$
\text { Hudjojo (Ujan, 2017:9) }
$$

mendefenisikan konsep matematika sebagai suatu ide abstrak yang memungkinkan kita mengklasifikasikan objek-objek dan peristiwa-peristiwa ke dalam ide abstrak tersebut (konsep matematika). Depdiknas (2003:2) menjelaskan bahwa pemahaman konsep merupakan salah satu kecakapan atau kemahiran matematika yang diharapkan dapat tercapai dalam belajar matematika yaitu dengan menunjukkan pemahaman konsep matematika yang dipelajarinya, menjelaskan keterkaitan antar konsep, dan mengaplikasikan algoritma secara luwes, akurat, efisien, dan tepat dalam pemecahan masalah. Adapun indikator pemahaman konsep menurut Departemen Pendidikan Nasional (2006) yaitu menyatakan ulang suatu konsep, mengklasifikasikan objek-objek menurut sifat-sifat tertentu (sesuai dengan konsepnya), memberikan contoh dan noncontoh dari konsep, menyajikan konsep dalam berbagai bentuk representasi matematis, mengembangkan syarat perlu atau syarat cukup suatu konsep, menggunakan, memanfaatkan, dan memilih prosedur atau operasi tertentu, dan mengaplikasikan konsep atau algoritma pemecahan masalah.

Agar pemahaman konsep matematika siswa meningkat, guru dituntut untuk menggunakan metode pembelajaran yang memicu kreatifitas dan daya berpikir matematika siswa. Namun, berdasarkan hasil wawancara dengan guru mata pelajaran matematika di SMP Santo Aloysius Turi diperoleh bahwa guru masih mengandalkan pendekatan pembelajaran konvensional yaitu tutor sebaya, metode ceramah dengan power point, dan latihan atau drill. Diketahui pula bahwa walaupun ketersediaan fasilitas 


\section{ASIMTOT: JURNAL KEPENDIDIKAN MATEMATIKA}

\section{Volume 2 Nomor 2, Juni - November 2020, halaman 177 - 192}

Tersedia Daring pada https://journal.unwira.ac.id/index.php/ASIMTOT

komputer di sekolah ini memadai yang ditunjukkan dengan adanya ruang laboratorium, multimedia, dan LCD pada masing-masing kelas, namun penggunaannya masih sangat terbatas. Berdasarkan hasil tes materi operasi ajabar pada siswa kelas VII $^{\mathrm{C}}$ SMP Santo Aloysius Turi yang dilaksanakan pada tanggal 13 Februari 2018, diketahui bahwa siswa kesulitan dalam menyelesaikan tes tersebut. Hal ini dikarenakan siswa tidak mengetahui konsep matematika apa yang harus digunakan dalam menyelesaikan permasalahan tersebut.

Menilik pada realita tersebut, sebenarnya konsep matematika yang dipandang abstrak ini dapat diaplikasikan menjadi suatu hal yang menarik dan inovatif sehingga mempermudah pemahaman konsep matematika siswa. Berdasarkan penelitian Hasanah (2012), penerapan VMME (Virtual Manipulative Mathematics in Education) dapat meningkatkan motivasi siswa dalam pembelajaran matematika yaitu: (1) menyukai guru matematika meningkat dari 9 siswa (21,95\%) menjadi 27 siswa $(69,23 \%)$, (2) memberikan perhatian pada penjelasan guru dalam proses pembelajaran meningkat dari 10 siswa $(24,39 \%)$ menjadi 35 siswa $(89,74 \%)$, (3) menanyakan materi yang tidak dipahami meningkat dari 10 siswa $(4,63 \%)$ menjadi 29 siswa (74,36\%), (4) antusias untuk melakukan penilaian tepat waktu meningkat dari 8 siswa $(19,51 \%)$ menjadi 35 siswa $(89,74 \%)$. Selanjutnya, Irawati (2017) menekankan penggunaan alat peraga virtual "Model Algebra Build the Equations" untuk meningkatkan ketertarikan siswa dalam memahami konsep penyelesaian persamaan linear satu variabel.

$$
\text { Moyer-Packenham }
$$
memberikan definisi tentang virtual manipulative is an interactive, technology enabled visual representation of a dynamic mathematical object, including all of the programmable features that allow it to be manipulated, that presents opportunities for constructing mathematical knowledge (virtual manipulative adalah sebuah media interaktif, teknologi melalui representasi visual yang menunjukkan objek matematika yang dinamis termasuk semua fitur program yang dapat dapat diperagakan, yang mana menunjukkan kesempatan untuk mengkonstruksikan pengetahuan matematika).

Oleh sebab itu, peneliti tertarik untuk menerapkan virtual manipulative dalam pembelajaran matematika. Hal ini bertujuan mempermudah siswa dalam memahami suatu konsep matematika. Pada penelitian ini, peneliti menggunakan indikator pemahaman konsep menurut Departemen Pendidikan Nasional (2006) yaitu menyatakan ulang setiap konsep, mengklasifikasikan objek menurut sifat-sifat tertentu (sesuai dengan konsepnya), menyajikan konsep dalam berbagai representasi matematis, serta menggunakan, memanfaatkan, dan memilih prosedur atau operasi tertentu dalam menyelesaikan masalah.

\section{Metode Penelitian}

Analisis data dalam penelitian ini menggunakan pendekatan kualitatif. Subjek penelitian ini adalah 24 siswa kelas VII ${ }^{\mathrm{A}}$ SMP 


\section{ASIMTOT: JURNAL KEPENDIDIKAN MATEMATIKA}

Volume 2 Nomor 2, Juni - November 2020, halaman 177 - 192

Tersedia Daring pada https://journal.unwira.ac.id/index.php/ASIMTOT

Santo Aloysius Turi Sleman Yogyakarta tahun ajaran 2018/2019. Subjek penelitian yang diwawancarai adalah siswa yang mewakili masing-masing kategori jawaban soal tes yaitu kategori tinggi, sedang, dan rendah. Teknik pengumpulan data dalam penelitian ini adalah observasi, tes tertulis (soal uraian yang disesuaikan dengan indikator pemahaman konsep), wawancara (wawancara tidak terstruktur) dan dokumentasi (foto dan rekaman wawancara). Pengumpulan data penelitian dilaksanakan pada bulan Oktober 2018 sampai Februari 2019.

Teknik analisis data pada penelitian ini meliputi reduksi data, pemaparan data, dan verifikasi. Peneliti mereduksi data hasil tes tertulis dan wawancara siswa pada materi operasi aljabar setelah mengikuti proses pembelajaran berbasis virtual manipulative berdasarkan pada indikator pemahaman konsep yaitu siswa dapat menyatakan ulang setiap konsep, siswa dapat mengklasifikasikan objek-objek menurut sifat-sifat tertentu (sesuai dengan konsepnya), siswa dapat menyajikan konsep dalam berbagai bentuk representasi matematis, serta siswa dapat menggunakan, memanfaatkan dan memilih prosedur atau operasi tertentu dalam menyelesaikan masalah. Selanjutnya, peneliti memaparkan data hasil reduksi tersebut dan diklasifikasikan dalam kategori tinggi, sedang, dan rendah. Kemudian data tersebut dianalisis dan dibahas untuk mengetahui pemahaman konsep siswa pada materi aljabar dengan menggunakan virtual manipulative. Hasil analisis tes tertulis dan wawancara siswa kelas $\mathrm{VII}^{\mathrm{A}}$ diverifikasi berdasarkan indikator pemahaman konsep. Selanjutnya, ditarik sebuah kesimpulan mengenai pemahaman konsep siswa pada materi operasi aljabar setelah mengikuti pembelajaran berbasis virtual manipulative.

\section{Hasil Penelitian dan Pembahasan}

\section{Hasil}

Penelitian ini dilaksanakan pada kelas VII $^{\text {A }}$ SMP St. Aloysius Turi Yogyakarta pada materi operasi aljabar yang berjumlah 24 siswa. Peneliti memberikan soal tes uraian yang telah divalidasi oleh dosen pembimbing dan guru mata pelajaran serta sesuai dengan indikator pemahaman konsep. Pemilihan subyek dilakukan berdasarkan hasil jawaban siswa dan hasil diskusi dengan guru mata pelajaran matematika. Berdasarkan kriteria diatas maka dipilih tiga siswa dengan hasil tes rendah, sedang, dan tinggi. Berdasarkan hasil pemecahan masalah dan wawancara yang telah dilakukan kepada ketiga subyek, maka diperoleh siswa dengan kemampuan rendah yaitu siswa yang menyusun kotak-kotak virtual belum tepat maupun menyatakan dalam bentuk aljabar yang belum tepat (12 siswa), siswa dengan kemampuan sedang yaitu siswa yang menyusun dengan tepat kotak-kotak virtual tersebut akan tetapi ketika menyatakan kedalam bentuk aljabar belum tepat (3 siswa), dan siswa dengan kemampuannya tinggi yaitu siswa yang menyusun kotak-kotak virtual dengan tepat dan menyatakan kedalam bentuk aljabar dengan tepat ( 9 siswa). Berikut adalah analisis 


\section{ASIMTOT: JURNAL KEPENDIDIKAN MATEMATIKA}

Volume 2 Nomor 2, Juni - November 2020, halaman 177 - 192

Tersedia Daring pada https://journal.unwira.ac.id/index.php/ASIMTOT

dan pembahasan kemampuan pemahaman konsep siswa dalam menyelesaikan masalah yang diberikan:

1. Siswa dengan Kemampuan Rendah (S1)

Berikut adalah analisis dan pembahasan kemampuan pemahaman konsep S1 berdasarkan data hasil pekerjaan dan wawancara siswa:

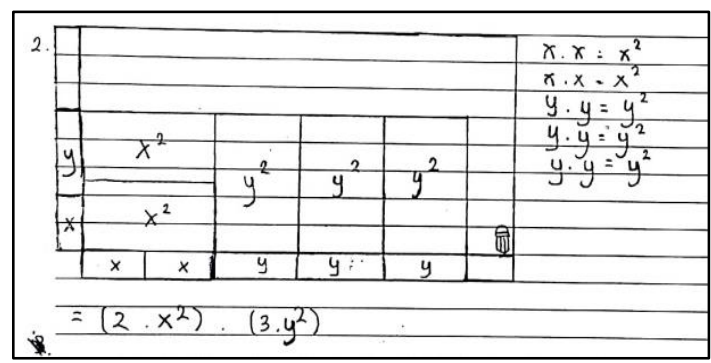

Gambar 1. Lembar Jawaban S1

P: Menurutmu apa saja yang diketahui dan ditanyakan dari soal-soal tersebut?

S1: Hm.., Menurut saya pak yang diketahui pada soal ada tabel aljabar kemudian kami diminta untuk membuat susunan kotak dalam tabel dan menyatakan kedalam bentuk aljabar pak. Sedangkan yang ditanya hasil perkalian dari dua suku aljabar.

P: Istilah-istilah atau simbol matematika apa yang kamu gunakan selama menyelesaikan soal ini?

S1: Ada $x, y, x^{2}, y^{2}$ dan perkalian pak.

P: Kalau dalam aljabar biasanya $x$ dan y itu disebut apa?

S1: Variabel kan pak.

P: Oke baik. Selain itu sesuai yang sudah kamu pelajari dalam aljabar apakah hanya itu saja?
S1: Hm.., Kalau tidak salah ada koefisien dan konstanta juga pak.

P: Kalau begitu apa beda antara koefisien dan kostanta menurutmu?

S1: Kalau koefisien berarti ada variabelnya lalu konstanta bilangan yang tidak punya variabel pak.

P: Kalau dari hasil pekerjaanmu, bisa kamu tunjukkan mana yang merupakan variabel dan konstanta?

S1: Hanya ada koefisien pak yaitu 2 dan 3 sedangkan konstantanya tidak ada.

P: Lalu konsep apa yang kamu gunakan dalam menentukan hasil perkalian kedua suku aljabar tersebut?

S1: Saya gunakan perkalian saja pak. Saya belum terlalu memahami cara membuat susunan dalam tabel itu.

P: Apakah kamu memahami gambar yang dibuat? Coba jelaskan!

S1: Jadi saya lihat kotak $x$ yang di samping kiri ada 1 dan kotak $x$ yang ada di bawah ada 2 pak, lalu masing-masing saya kalikan sehingga memperoleh 2 susunan kotak $x^{2}$. Begitu juga pada $y$, kotak $y$ yang ada di samping ada 1 sedangkan yang ada dibawah ada 3, lalu saya kalikan sehingga dapat 3 kotak $y^{2}$.

P: Jadi seperti itu, kalau begitu apakah susunan itu kamu gambarkan begitu saja ataukah adakah cara untuk membuat susunan seperti itu?

S1: Saya susun sesuai kotak dibawah pak. Jadi $x^{2}$ ada 2 dan $y^{2}$ ada 3.

P: Bagaimana caramu sehingga memperoleh hasil kali perkaliannya $2 x^{2} .3 y^{2}$ ? 


\section{ASIMTOT: JURNAL KEPENDIDIKAN MATEMATIKA}

Volume 2 Nomor 2, Juni - November 2020, halaman 177 - 192

Tersedia Daring pada https://journal.unwira.ac.id/index.php/ASIMTOT

S1: Dari susunan kotak yang didapat saya menghitung banyak kotak $x^{2}$ kan ada 2 dan $y^{2}$ ada 3 pak jadi saya tulis seperti itu.

P: Apa maksud kamu membuat gambar seperti ini?

S1: Untuk menentukan hasil perkalian dari kedua suku aljabar pak. Saya membuat gambar susunan kotak dalam tabel untuk mengetahui hasil perkalian dua suku tersebut.

P: Mengapa pada hasil perkalian kamu menuliskan $2 x^{2} .3 y^{2}$ ?

S1: Hm.., Karena yang ditanyakan hasil perkalian jadi saya tulis seperti ini pak.

P: Kalau begitu apakah kamu tahu dua suku aljabar yang mau kamu kalikan untuk mengetahui hasilnya?

S1: Ada $x$ dikali $2 x$ dan y dikali $3 y$ pak.

P: Baik, kalau begitu apa hasil atau kesimpulan yang kamu peroleh dari menyelesaikan masalah ini?

S1: Ya, hasil perkaliannya $2 x^{2} .3 y^{2}$ pak.

$P$ : Baik, selanjutnya, bagaimana hubungan antara operasi aljabar dan bangun datar berdasarkan proses penyelesaian yang telah kamu lakukan?

S1: Bisa ada hubungan pak. Terletak pada susunan kotak yang dapat dibuat aljabar mungkin pak.

P: Baik, apakah kamu bisa menyebutkan strategi atau langkah yang kamu lakukan untuk menyelesaikan soal tersebut?

S1: Jadi, pertama saya membuat gambar susunan kotak aljabar pak, untuk menentukan hasil perkalian dua suku aljabar, kemudian saya membuat kesimpulan daei susunan kotak dan terakhir saya menghitung banyak kotak yang ada pada susunan tersebut.

P: Apakah kamu yakin dengan jawabanmu? Pada bagian mana anda mengalami kesulitan?

S1: Saya masih kurang yakin pak, pada susunan kotak yang saya buat untuk menentukan hasil perkalian dua suku aljabar pak.

Berdasarkan hasil jawaban dan wawancara S1 diatas, terlihat bahwa dalam menyelesaikan masalah yang diberikan, S1 mencoba membuat susunan kotak-kotak yang sesuai dengan persegi panjang untuk menentukan hasil perkalian kedua bentuk aljabar yang terdapat pada susunan kotak vertikal maupun kotak horizontal, akan tetapi S1 memperoleh susunan yang belum tepat. Selanjutnya, S1 belum mampu mengaitkan susunan kotak yang berada pada panjang dan lebar persegi panjang tersebut. Disini S1 hanya mengaitkan kotak $\boldsymbol{x}$ yang berada pada lebar dengan 2 kotak $\boldsymbol{x}$ yang berada pada panjang persegi panjang dan begitu juga dengan kotak $\boldsymbol{y}$ pada lebar persegi panjang dengan $\mathbf{3}$ kotak $\boldsymbol{y}$ pada panjang persegi panjang sehingga kotak yang berada dalam persegi panjang tersebut adalah 2 kotak $\boldsymbol{x}^{\mathbf{2}}$ dan 3 kotak $\boldsymbol{y}^{\mathbf{2}}$. Selanjutnya, S1 membuat kesimpulan dari proses penyelesaian yang dilakukannya dengan menuliskan hasil perkalian $\boldsymbol{x} \cdot \boldsymbol{x}=\boldsymbol{x}^{2}, \boldsymbol{x} \cdot \boldsymbol{x}=$ $x^{2}, y \cdot y=y^{2}, y \cdot y=y^{2}, y \cdot y=y^{2}$.

Berdasarkan kesimpulan dan susunan yang telah diperolehnya, maka S1 menyatakan bentuk aljabar dari hasil penyelesaian masalah 


\section{ASIMTOT: JURNAL KEPENDIDIKAN MATEMATIKA}

Volume 2 Nomor 2, Juni - November 2020, halaman 177 - 192

Tersedia Daring pada https://journal.unwira.ac.id/index.php/ASIMTOT

tersebut yaitu $\left(\mathbf{2} \cdot \boldsymbol{x}^{\mathbf{2}}\right) \cdot\left(\mathbf{3} \cdot \boldsymbol{y}^{\mathbf{2}}\right)$. Pada indikator menyatakan ulang setiap konsep, S1 belum mampu menyatakan dengan tepat susunan kotak-kotak untuk menunjukkan hasil perkalian kedua bentuk aljabar tersebut, S1 belum mengaitkan bentuk aljabar pada lebar dan panjang persegi panjang tersebut sesuai dengan hasil yang diperoleh, sehingga dapat disimpulkan S1 belum memenuhi indikator menyatakan ulang setiap konsep. Pada indikator mengklasifikasikan objek-objek menurut sifat-sifat tertentu (sesuai dengan konsepnya), S1 tidak mampu mengklasifikasikan susunan kotak yang sesuai dengan susunan kotak aljabar pada panjang dan lebar persegi panjang tersebut, S1 tidak mampu menyatakan bentuk aljabar dengan tepat sesuai dengan kotak virtual yang disusunnya. Selanjutnya, S1 mampu menjelaskan proses penyusunan atau pembuatan gambar yang dilakukannya, akan tetapi S1 tidak melihat hubungan antara susunan kotak pada bagian vertikal dan horizontal dari tabel aljabar tersebut, sehingga mengakibatkan susunan kotak aljabar yang belum tepat dan hasil yang ditunjukkan juga belum tepat, sehingga dapat disimpulkan S1 belum memenuhi indikator mengklasifikasikan objek-objek menurut sifat-sifat tertentu (sesuai dengan konsepnya). Pada indikator menyajikan konsep dalam berbagai bentuk representasi matematis, S1 mampu menyatakan proses penyelesaian terhadap masalah yang diberikan dalam bentuk gambar maupun simbol matematika. Selanjutnya, S1 mampu menjelaskan gambar yang telah dibuat, menjelaskan hubungan antara bangun datar dengan bentuk aljabar yang telah diperoleh walaupun jawabannya belum tepat, sehingga dapat disimpulkan S1 sudah mampu memenuhi indikator menyajikan konsep dalam berbagai bentuk representasi matematis. Pada indikator menggunakan, memanfaatkan, dan memilih prosedur atau operasi tertentu dalam menyelesaikan masalah, S1 mempunyai langkah-langkah tertentu hingga memperoleh hasil jawaban dari masalah yang diberikan walaupun jawaban yang diberikan masih belum tepat. Selanjutnya, terlihat bahwa S1 mampu menyebutkan langkah-langkah yang digunakannya dalam menyelesaikan soal tersebut, kemudian menyebutkan kesulitan yang dihadapinya artinya siswa tersebut menyadari kekurangan yang dimilikinya, sehingga dapat disimpulkan S1 sudah memenuhi indikator menggunakan, memanfaatkan dan memilih prosedur atau operasi tertentu dalam menyelesaikan masalah.

2. Siswa dengan kemampuan sedang (S2)

Berikut adalah analisis dan pembahasan kemampuan pemahaman konsep S2 berdasarkan data hasil pekerjaan dan wawancara siswa:

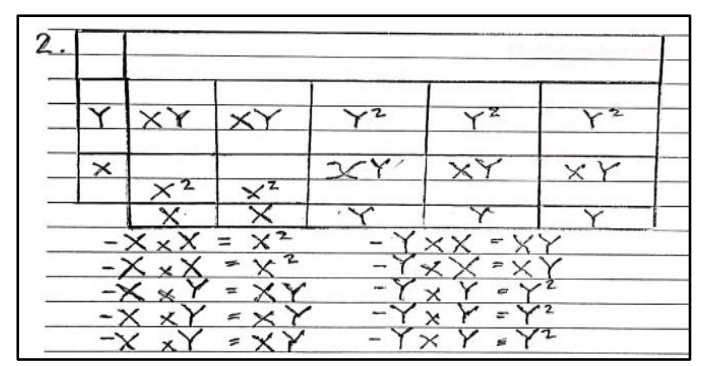

Gambar 2. Lembar Jawaban S2 


\section{ASIMTOT: JURNAL KEPENDIDIKAN MATEMATIKA}

Volume 2 Nomor 2, Juni - November 2020, halaman 177 - 192

Tersedia Daring pada https://journal.unwira.ac.id/index.php/ASIMTOT

P: Bisakah kamu menyebutkan apa saja yang diketahui dan ditanyakan dari soal tersebut?

S2: Bisa pak, yang diketahui pada soal ada gambar tabel aljabar. Sedangkan yang ditanyakan membuat suku-suku aljabar yang ada dalam tabel dan menentukan hasil perkalian kedua suku aljabar pak.

P: Istilah-istilah atau simbol matematika apa yang kamu gunakan selama menyelesaikan soal-soal tersebut?

S2: $x, y, x y$, tanda kali, $x^{2}$ dan $y^{2}$ pak.

P: Oke, baik untuk semua yang tadi sudah kamu sebutkan biasanya dikenal dengan istilah apa?

S2: Kalau tidak salah variabel pak.

P: Berdasarkan yang sudah kamu pelajari, coba kamu sebutkan istilah selain variabel tadi beserta contohnya.

S2: Koefisien dan kostanta pak. Contohnya kalau koefisien $2 x$ atau $5 y$ sedangkan konstanta 12, atau 20 pak.

P: Baik, selain yang sudah kamu sebutkan, apakah masih ada konsep yang lain yang digunakan?

S2: Kalau melihat dari tabelnya berbentuk persegi panjang pak, sehingga pakai rumus luas persegi panjang ada panjang kali lebar juga pak.

$P$ : Lalu apa tujuan kamu menuliskan $x . x=x^{2}$, $x \cdot y=x y$ dan $y \cdot y=y^{2}$, dst. Seperti ini?

S2: Itu untuk menunjukkan hasil perkalian dua suku aljabar itu pak.

P: Baik, kalau dilihat dari hasil pekerjaanmu ini, bisakah kamu menunjukkan dua suku aljabar yang ingin kamu ketahui hasil perkaliannya?
S2: Pada samping kiri ini ada y dan x lalu dibawahnya $x$ ada 2 dan y ada 3 pak.

P: Lalu bisakah kamu menyederhanakan bentuk-bentuk aljabar yang sudah diperoleh ini menjadi hasil perkalian dari dua suku tersebut?

S2: Saya masih bingung disitu pak.

P: Apakah kamu memahami gambar yang telah dibuat ini? Coba jelaskan!

S2: Iya pak. Jadi untuk kotak yang ada di kiri dan bawah tabel kan sudah ada pak. Lalu untuk menentukan hasil perkalian dua suku aljabar itu, saya buat susunan kotak yang dapat memenuhi tabel pak.

P: Bagaimana caramu sehingga dapat membuat susunan kotak seperti ini?

S2: Saya kalikan antara variabel di panjang dan lebar kotak pak. Seperti kesimpulan ini yang saya buat. Jadi $x$ kali $x$ hasilnya $x^{2}, x$ kali $y$ hasilnya $x y$ dan $y$ kali $y$ hasilnya $y^{2}$ pak.

P: Baik. Kembali lagi pada gambar yang dibuat, apa tujuanmu membuat gambar seperti ini?

S2: Untuk menjawab soal yang diberikan kan pak. Jadi, gambar ini digunakan untuk dapat menentukan hasil perkalian dua suku aljabar.

$P$ : Lalu apa tujuan kamu menuliskan $x . x=x^{2}$, $x . y=x y$ dan $y . y=y^{2}$, dst. Seperti ini?

S2: Itu untuk menunjukkan hasil perkalian dua suku aljabar itu pak.

P: Baik, kalau dilihat dari hasil pekerjaanmu ini, bisakah kamu menunjukkan dua suku aljabar yang ingin kamu ketahui hasil perkaliannya? 


\section{ASIMTOT: JURNAL KEPENDIDIKAN MATEMATIKA}

Volume 2 Nomor 2, Juni - November 2020, halaman 177 - 192

Tersedia Daring pada https://journal.unwira.ac.id/index.php/ASIMTOT

S2: Pada samping kiri ini ada y dan $x$ lalu dibawahnya $x$ ada 2 dan y ada 3 pak.

P: Lalu bisakah kamu menyederhanakan bentuk-bentuk aljabar yang sudah diperoleh ini menjadi hasil perkalian dari dua suku tersebut?

S2: Saya masih bingung disitu pak.

P: Menurut kamu bagaimana hubungan antara operasi aljabar dan bangun datar sesuai dengan hasil yang telah kamu peroleh?

S2: Dengan menggunakan bangun datar kita bisa menentukan hasil perkalian dua suku aljabar pak.

P: Baik, dari penjelasan yang sudah kamu sampaikan, apakah kamu dapat menyebutkan langkah-langkah yang digunakan dalam menyelesaikan masalah?

S2: Pertama gambar tabel aljabar pak, kedua membuat susunan kotak aljabar dalam tabel tersebut, dan ketiga menuliskan hasil perkalian kedua suku aljabar pak.

P: Apakah kamu yakin dengan jawabanmu? Pada bagian mana anda mengalami kesulitan?

S2: Tidak terlalu yakin pak. Ada pak, pada bagian membuat kesimpulan dari hasil perkalian kedua suku aljabar pak.

Berdasarkan hasil jawaban S2 pada masalah tersebut, diperoleh bahwa S2 menggunakan representasi gambar untuk menyimpulkan hasil perkalian kedua bentuk aljabar tersebut. Selanjutnya, S2 dalam menyatakan susunan kotak-kotak tersebut sudah tepat dengan menghubungkan kotak virtual yang ada pada baris vertikal maupun horizontal. Hal ini dilihat pula pada kesimpulan bentuk aljabar yang dinyatakan sebagai hasil perkalian kedua bentuk aljabar tersebut. Berdasarkan kesimpulan pada gambar diatas diketahui bahwa $x \times x=x^{2}, x \times x=x^{2}, x \times y=x y$, $x \times y=x y, x \times y=x y, x \times y=x y$, $x \times y=x y, y \times y=y^{2}, y \times y=y^{2}, y \times$ $\boldsymbol{y}=\boldsymbol{y}^{\mathbf{2}}$. Pada indikator menyatakan ulang setiap konsep terlihat bahwa S2 mampu membuat susunan kotak yang tepat untuk menunjukkan hasil perkalian dua suku aljabar tersebut akan tetapi S2 belum mampu menyatakan kedalam bentuk aljabar dari susunan kotak-kotak tersebut secara tepat walaupun sudah membuat kesimpulan berdasarkan susunan kotak yang telah diperoleh. S2 mampu menyebutkan yang diketahui dan ditanyakan pada soal, istilahistilah yang digunakan dalam menyelesaikan masalah, akan tetapi S2 belum mampu menyatakan bentuk aljabar sebagai hasil perkalian kedua suku aljabar tersebut. Sehingga dapat disimpulkan S2 belum mampu memenuhi indikator menyatakan ulang setiap konsep. Pada indikator mengklasifikasikan objek-objek tertentu menurut sifat-sifat tertentu (sesuai dengan konsepnya), terlihat bahwa S2 dalam menyatakan susunan kotak virtual sudah mampu mengaitkan antara kotak aljabar yang terdapat pada panjang dan lebar persegi panjang tersebut, sehingga susunan yang digambarkan sudah tepat. Selanjutnya, dalam menyatakan susunan kotak yang telah dibuat kedalam bentuk aljabar, S2 mengalami kesulitan dalam bentuk aljabar yang tepat sehingga yang dituliskan oleh S2 merupakan 


\section{ASIMTOT: JURNAL KEPENDIDIKAN MATEMATIKA}

Volume 2 Nomor 2, Juni - November 2020, halaman 177 - 192

Tersedia Daring pada https://journal.unwira.ac.id/index.php/ASIMTOT

kesimpulan dari proses perkalian antara masing-masing variabel pada bentuk aljabar tersebut. S2 mampu mengklasifikasikan susunan kotak pada panjang dan lebar persegi panjang sehingga dapat membuat susunan kotak virtual tersebut dengan tepat hanya saja S2 belum mampu menyelesaikan masalah dengan tepat. Lebih lanjut S2 mampu menjelaskan kaitan antara kotak aljabar yang berada pada lebar dan panjang tabel tersebut yang mengakibatkan susunan kotak yang memenuhi tabel dapat dibuat secara tepat, akan tetapi S2 belum dapat mengklasifikasikan suku-suku aljabar yang menjadi hasil perkalian kedua bentuk aljabar yang diketahui, sehingga dapat disimpulkan S2 belum mampu memenuhi indikator mengklasifikasikan objek-objek menurut sifat-sifat tertentu (sesuai dengan konsepnya). Pada indikator menyajikan konsep dalam berbagai bentuk representasi matematis, S2 mampu menyatakan proses penyelesaian terhadap masalah yang diberikan dalam bentuk gambar maupun simbol matematika. Selanjutnya, S2 mampu menjelaskan maksud dari gambar maupun simbol yang telah dibuatnya, menyebutkan suku-suku aljabar yang diketahui dengan kata-kata, sehingga dapat disimpulkan S2 sudah mampu memenuhi indikator menyajikan konsep dalam berbagai bentuk representasi matematis. Pada indikator menggunakan, memanfaatkan, dan memilih prosedur atau operasi tertentu dalam menyelesaikan masalah, S2 mempunyai langkah-langkah tertentu hingga memperoleh hasil jawaban dari masalah yang diberikan walaupun jawaban yang diberikan belum sesuai dengan penyelesaian masalah yang diharapkan. Selanjutnya, S2 dapat menyebutkan langkahlangkah yang digunakan dalam menyelesaikan masalah, mengetahui kesulitan yang dihadapi dalam menyelesaikan soal tersebut, sehingga dapat disimpulkan S2 sudah mampu memenuhi indikator menggunakan, memanfaatkan dan memilih prosedur atau operasi tertentu dalam menyelesaikan masalah.

3. Siswa dengan kemampuan tinggi (S3)

Berikut adalah analisis dan pembahasan kemampuan pemahaman konsep S3 berdasarkan data hasil pekerjaan dan wawancara siswa:

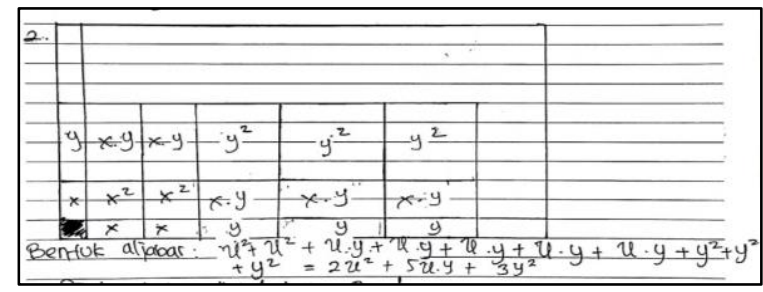

Gambar 2. Lembar Jawaban S3

P: Apa saja yang diketahui dan ditanyakan dari soal tersebut?

S3: Diketahui ada gambar tabel aljabar yang memuat dua suku aljabar pak. Susunan pertama y dan $x$, lalu susunan kedua $2 x$ dan 3y. Kalau yang ditanya menentukan hasil perkalian kedua suku aljabar dan menyatakan dalam bentuk aljabar pak.

P: Istilah-istilah atau simbol matematika apa yang kamu gunakan selama menyelesaikan soal-soal tersebut?

S3: $x, y, x y, x^{2}, y^{2},+, \times,=$ pak.

P: Baik, kalau begitu biasanya $x$ dan $y$ ini disebut apa? 


\section{ASIMTOT: JURNAL KEPENDIDIKAN MATEMATIKA}

Volume 2 Nomor 2, Juni - November 2020, halaman 177 - 192

Tersedia Daring pada https://journal.unwira.ac.id/index.php/ASIMTOT

S3: Variabel pak.

P: Selain variabel, apa lagi yang sudah kamu pelajari dalam aljabar?

S3: Ada koefisien variabel dan suku sejenis pak.

P: Baik, kalau begitu dari jawabanmu, bisakah kamu menunjukkan mana yang merupakan koefisien, kostanta, dan suku sejenis?

S3: Kalau koefisien 2, 5 dan 3. Kalau konstanta disini tidak ada pak. Sedangkan suku sejenis ada $2 x y$ dan 3xy pak.

P: Baik, selanjutnya apakah kamu memahami gambar yang dibuat? Coba jelaskan!

S3: Iya pak. Karena pada soal sudah ada tabel aljabar, dimana pada lebarnya ada kotak aljabar $x$ dan $y$ kemudian pada panjangnya ada $2 x$ dan $3 y$. Ini juga diperhatikan untuk dapat menyusun kotak yang benar dalam tabel tersebut pak. Jadi $x$ dikali $x$ menjadi $x^{2}, x$ dikali $y$ jadinya $x y, y$ dikali $x$ jadinya $x y$, lalu $y$ dikali y jadinya $y^{2}$. Sehingga susunannya sesuai dengan hasil perkaliannya pak.

P: Baik kalau begitu, selanjutnya dalam lembar jawabanmu, disini kamu menuliskan $2 x^{2}+5 x y+3 y^{2}$, bisa dijelaskan bagaimana sehingga kamu memperoleh jawaban seperti itu?

S3: Dari bentuk aljabar yang diperoleh dari susunan kotak dalam tabel jadinya $x^{2}$ ada 2 pak, lalu xy ada 5 dan $y^{2}$, sehingga saya tuliskan seperti itu.

P: Bagaimana kamu dapat menyimpulkan hasil perkalian dari kedua bentuk aljabar tersebut?
S3: Jadi, hasil perkalian $y+x$ dan $2 x+3 y$ itu adalah $2 x^{2}+5 x y+3 y^{2}$.

P: Baik, selanjutnya apakah kamu memahami gambar yang dibuat? Coba jelaskan!

S3: Iya pak. Karena pada soal sudah ada tabel aljabar, dimana pada lebarnya ada kotak aljabar $x$ dan y kemudian pada panjangnya ada $2 x$ dan 3y. Ini juga diperhatikan untuk dapat menyusun kotak yang benar dalam tabel tersebut pak. Jadi $x$ dikali $x$ menjadi $x^{2}, x$ dikali $y$ jadinya $x y, y$ dikali $x$ jadinya $x y$, lalu $y$ dikali y jadinya $y^{2}$. Sehingga susunannya sesuai dengan hasil perkaliannya pak.

P: Baik kalau begitu, selanjutnya dalam lembar jawabanmu, disini kamu menuliskan $2 x^{2}+5 x y+3 y^{2}$, bisa dijelaskan bagaimana sehingga kamu memperoleh jawaban seperti itu?

S3: Dari bentuk aljabar yang diperoleh dari susunan kotak dalam tabel jadinya $x^{2}$ ada 2 pak, lalu xy ada 5 dan $y^{2}$, sehingga saya tuliskan seperti itu.

P: Apa tujuanmu membuat gambar seperti itu?

S3: Gambar itu dibuat untuk dapat menentukan hasil perkalian kedua bentuk aljabar yang ada pada panjang dan lebar tabel tersebut.

P: Bagaimana kamu dapat menyimpulkan hasil perkalian dari kedua bentuk aljabar tersebut?

S3: Jadi, hasil perkalian $y+x$ dan $2 x+3 y$ itu adalah $2 x^{2}+5 x y+3 y^{2}$.

P: Baik, pak ingin tahu mengapa pada bentuk aljabar yang dibuat semuanya kamu 


\section{ASIMTOT: JURNAL KEPENDIDIKAN MATEMATIKA}

Volume 2 Nomor 2, Juni - November 2020, halaman 177 - 192

Tersedia Daring pada https://journal.unwira.ac.id/index.php/ASIMTOT

menggunakan tanda tambah bukan kurang ataukah kali?

S3: Itu karena untuk menuliskan bentuk aljabar dari hasil kali kedua suku aljabar kan positif semua, dan juga hasilnya kan digabung pak.

P: Bagaimana hubungan antara operasi aljabar dan bangun datar menurutmu berdasarkan hasil pekerjaanmu?

S3: Ada hubungannya pak, yaitu dalam menentukan hasil perkalian aljabar sama dengan luas pada persegi panjang.

P: Berdasarkan proses jawabanmu ini, dapatkah kamu menyebutkan langkahlangkah sampai dengan memperoleh hasil jawabanmu terhadap masalah tersebut?

S3: Jadi, pertama-tama saya menentukan susunan kotak yang ada dalam tabel aljabar, kemudian menyatakan hasil susunan kedalam bentuk aljabar dan yang terakhir menyederhanakan bentuk aljabar yang sudah didapat.

P: Apakah kamu yakin dengan jawabanmu? Pada bagian mana anda mengalami kesulitan?

S3: Iya yakin pak. Tidak ada pak, karena saya memperhatikan saat pak menjelaskan.

Berdasarkan hasil jawaban S3 diatas, terlihat bahwa dalam menyelesaikan masalah yang diberikan, S3 membuat susunan kotak-kotak yang sesuai dengan persegi panjang untuk menentukan hasil perkalian kedua bentuk aljabar yang terdapat pada susunan kotak vertikal maupun kotak horizontal yang diketahui dari soal dengan tepat. Dari susunan kotak yang telah digambarkan diperoleh bahwa S3 mengaitkan antara kotak $x$ dengan kotak $x$ menjadi $x^{2}$, kotak $x$ dengan $y$ menjadi $x y$, kotak $y$ dengan $x$ menjadi $x y$ dan kotak $y$ dengan $y$ menjadi $y^{2}$. Disini menunjukkan, S3 memahami dengan baik konsep luas persegi panjang dengan mengaitkan susunan kotak yang ada pada baris vertikal dan horizontal bentuk virtual tersebut, sehingga susunan kotak yang dituliskan menjadi tepat. Selanjutnya, S3 menyatakan susunan kotak untuk menunjukkan hasil perkalian kedua bentuk aljabar tersebut kedalam bentuk aljabar yaitu $x^{2}+x^{2}+x \cdot y+x \cdot y+x \cdot y+x \cdot y+$ $x \cdot y+y^{2}+y^{2}+y^{2}$. Selanjutnya, untuk menunjukkan hasil perkalian kedua bentuk aljabar tersebut, maka S3 menyederhanakan bentuk aljabar tersebut dan menyatakan hasilnya yaitu $2 x^{2}+5 x y+3 y^{2}$, dimana diperoleh dari menggunakan sifat distributive yaitu $x^{2}(1+1)+x y(1+1+1+1+1)+$ $y^{2}(1+1+1)$. Pada indikator menyatakan ulang setiap konsep terlihat bahwa S3 mampu menyatakan konsep luas persegi panjang dengan tepat sehingga susunan kotak menjadi tepat, kemudian menyatakan susunan kotak pada persegi panjang sebagai hasil perkalian dua suku aljabar dengan tepat. Selanjutnya, S3 mampu menyatakan bentuk aljabar untuk menyatakan hasil perkalian kedua bentuk aljabar tersebut. S3 mampu menyebutkan yang diketahui dan ditanyakan dari soal, menyebutkan istilah-istilah atau simbol yang digunakan dalam menyelesaikan masalah tersebut, menjelaskan konsep yang digunakan untuk menyelesaikan masalah, sehingga dapat disimpulkan S3 sudah mampu memenuhi 


\section{ASIMTOT: JURNAL KEPENDIDIKAN MATEMATIKA}

Volume 2 Nomor 2, Juni - November 2020, halaman 177 - 192

Tersedia Daring pada https://journal.unwira.ac.id/index.php/ASIMTOT

indikator menyatakan ulang setiap konsep. Pada indikator mengklasifikasikan objekobjek menurut sifat-sifat tertentu (sesuai dengan konsepnya), S3 mampu mengklasifikasikan susunan yang tepat untuk menyatakan hasil perkalian kedua bentuk aljabar tersebut, menyederhanakan bentuk aljabar dari susunan kotak yang telah dibentuknya sesuai dengan suku-suku yang sejenis dan menyatakan gabungan dari variabel bentuk aljabar tersebut dengan menggunakan sifat distributive dengan tepat. S3 mampu menjelaskan kaitan antara kotak aljabar yang berada pada lebar dan panjang tabel tersebut sehingga dapat menyusun kotak-kotak aljabar yang tepat kedalam tabel, menjelaskan cara menyederhanakan bentuk aljabar yang telah diperoleh dengan tepat, sehingga dapat disimpulkan S3 sudah memenuhi indikator mengklasifikasikan objek-objek menurut sifat-sifat tertentu (sesuai dengan konsepnya). Pada indikator menyajikan konsep dalam berbagai bentuk representasi matematis, S3 mampu menyatakan proses penyelesaian terhadap masalah yang diberikan dalam bentuk gambar maupun simbol matematika. Selanjutnya, S3 mampu menjelaskan proses penyelesaian masalah, menjelaskan gambar yang telah dibuatnya maupun simbol yang digunakan dalam menyelesaikan masalah, sehingga dapat disimpulkan S3 mampu memenuhi indikator menyajikan konsep dalam berbagai bentuk representasi matematis. Pada indikator menggunakan, memanfaatkan, dan memilih prosedur atau operasi tertentu dalam menyelesaikan masalah, S3 mempunyai langkah-langkah tertentu hingga memperoleh hasil jawaban dari masalah yang diberikan. S3 dapat menyebutkan langkah-langkah yang digunakan dalam menyelesaikan masalah, yakin dengan jawaban yang telah diperolehnya, sehingga dapat disimpulkan S3 sudah mampu memenuhi indikator menggunakan, memanfaatkan dan memilih prosedur atau operasi tertentu dalam menyelesaikan masalah.

\section{Pembahasan}

Penelitian Moyer-packenham (2012), melihat tentang siswa dengan kemampuan rendah dibagi kedalam dua kelompok yaitu kelompok pertama diajarkan dengan menggunakan virtual manipulative (dynamic virtual manipulative) dan situs yang dipakai adalah website National Library of Virtual Manipulatives (www.nlvm.usu.edu). Kelompok yang kedua diajarkan menggunakan model bergambar (static pictorial manipulative) berkaitan dengan materi pada pecahan. Peneliti menyimpulkan bahwa siswa dalam kelompok DVM dan SPM menunjukkan signifikan perbaikan antara pretest dan post test pada konsep pecahan. Kemampuan visualisasi siswa meningkat saat menggunakan model bergambar, baik dalam modalitas statis maupun dinamis. Selanjutnya, dalam penelitian Nyoman Tiya Martini (2015), meneliti dua kelompok dimana satunya menjadi kelas eksperimen yang diajarkan dengan menggunakan software matematika dan kelas kontrol yang diajarkan dengan menggunakan metode konvensional. Software yang digunakan dalam penelitian ini 


\section{ASIMTOT: JURNAL KEPENDIDIKAN MATEMATIKA}

Volume 2 Nomor 2, Juni - November 2020, halaman 177 - 192

Tersedia Daring pada https://journal.unwira.ac.id/index.php/ASIMTOT

adalah geogebra dan mathematica. Peneliti menyimpulkan bahwa pemahaman konsep matematika siswa yang mengikuti pemanfaatan software matematika dalam model problem based learning lebih baik daripada pemahaman konsep matematika siswa yang mengikuti pembelajaran konvensional. Dalam penelitian Ismail Hanif Batubara (2017), menunjukkan peningkatan kemampuan pemahaman konsep matematik siswa SMA melalui model pembelajaran berbasis masalah berbantuan Autograph lebih tinggi daripada peningkatan kemampuan pemahaman konsep matematika siswa yang memperoleh model pembelajaran berbasis masalah berbantuan Geogebra dan tidak terdapat interaksi antara pembelajaran dengan kemampuan awal siswa terhadap kemampuan peningkatan pemahaman konsep matematika.

Penelitian-penelitian yang berkaitan dengan memanfaatkan IT dan melihat dampaknya selama proses pembelajaran sebagian besar menggunakan penelitian kuantitatif untuk membandingkan peningkatan kualitas hasil belajar siswa terhadap pendekatan belajar yang lain. Pada penelitian ini menggunakan virtual manipulative algebra tiles pada situs NLVM dan pengaruhnya terhadap kemampuan pemahaman konsep siswa.

\section{Simpulan dan Saran}

\section{Simpulan}

Pemahaman konsep matematika siswa kelas VII pada materi operasi aljabar setelah mengikuti proses pembelajaran matematika dengan virtual manipulative adalah sebagai berikut:

1. Berdasarkan deskripsi jawaban dan kutipan wawancara S1, dapat disimpulkan bahwa S1 sudah memenuhi indikator pemahaman konsep yaitu menyajikan konsep dalam berbagai bentuk representasi matematis, dan menggunakan, memanfaatkan, dan memilih prosedur atau operasi tertentu dalam menyelesaikan masalah.

2. Berdasarkan deskripsi jawaban dan kutipan wawancara S2, dapat disimpulkan bahwa S2 sudah memenuhi indikator pemahaman konsep yaitu menyajikan konsep dalam berbagai bentuk representasi matematis, dan menggunakan, memanfaatkan, dan memilih prosedur atau operasi tertentu dalam menyelesaikan masalah.

3. Berdasarkan deskripsi jawaban dan kutipan wawancara S3, dapat disimpulkan bahwa S3 sudah memenuhi indikator pemahaman konsep yaitu menyatakan ulang setiap konsep, mengklasifikasikan konsep menurut sifat-sifat tertentu (sesuai dengan konsepnya), menyajikan konsep dalam berbagai bentuk representasi matematis, dan menggunakan, memanfaatkan, dan memilih prosedur atau operasi tertentu dalam menyelesaikan masalah.

\section{Saran}

Berdasarkan kesimpulan hasil penelitian yang diperoleh dan pengalaman selama penelitian, maka peneliti memberikan saran-saran sebagai berikut: 


\section{ASIMTOT: JURNAL KEPENDIDIKAN MATEMATIKA}

Volume 2 Nomor 2, Juni - November 2020, halaman 177 - 192

Tersedia Daring pada https://journal.unwira.ac.id/index.php/ASIMTOT

1. Saran bagi siswa, untuk dapat memperhatikan dengan seksama proses pembelajaran yang terjadi di dalam kelas sehingga dapat memahami setiap penjelasan yang diberikan oleh guru dengan baik. Maupun aktif dalam proses diskusi dalam menentukan penyelesaian dari masalah yang diberikan.

2. Saran bagi guru, perlu memperhatikan koneksi jaringan selama proses pembelajaran berlangsung sehingga menghindarkan kendala-kendala yang dapat mengganggu berlangsungnya proses pembelajaran dan menambahkan informasi mengenai virtual manipulative kepada siswa sebelum diberikan perlakuan sehingga dapat menghemat waktu dalam proses pembelajaran.

3. Saran bagi sekolah, menerapkan komputer sebagai media dalam proses pembelajaran dibutuhkan perhatian serta ketelitian yang intens dan mendalam. Perlu memperhatikan alur pembelajaran yang sudah disiapkan agar sesuai dengan harapan yang sudah kita impikan. Kesalahan dalam menyampaikan penjelasan ataupun materi dapat mempengaruhi siswa untuk memahami konsep yang ingin kita bangun.

4. Saran bagi peneliti selanjutnya, karena pada penelitian ini menggunakan data kelompok selama proses pembelajaran sehingga proses mengkontruksikan pengetahuan pada masing-masing individu menjadi terbatas. Oleh karenanya, diharapkan dalam penelitian-penelitian selanjutnya dapat memfokuskan pada keterlaksanaan proses pembelajaran pada masing-masing individu.

\section{Daftar Pustaka}

Batubara, Ismail Hanif. (2017). Peningkatan Kemampuan Pemahaman Konsep Matematis melalui Model Pembelajaran Berbasis Masalah Berbantuan Autograph dan Geogebra di SMA Freemethodist Medan. Journal of Mathematics Education and Science. Vol.3. No 1. Oktober 2017.

Departemen Pendidikan Nasional, 2006. Standar Isi untuk Satuan Pendidikan Dasar dan Menengah. Jakarta: Departemen Pendidikan Nasional Dikrektorat Pendidikan Dasar dan Menengah.

Duffin, J.M. \& Simpson, A.P. (2000). A Search for Understanding. Journal of Mathematical Behavior. 18 (4): 415 427.

Hasanah, Agustina Nurul. (2012). Penerapan VMEE (Virtual Manipulative Mathematics in Education) untuk Meningkatkan Motivasi Belajar Matematika Siswa. Skripsi. FKIP Universitas Muhammadiyah Surakarta. Surakarta.

Irawati, Magdalena dkk. (2017). Pemanfaatan Alat Peraga Virtual Model Algebra 


\section{ASIMTOT: JURNAL KEPENDIDIKAN MATEMATIKA}

Volume 2 Nomor 2, Juni - November 2020, halaman 177 - 192

Tersedia Daring pada https://journal.unwira.ac.id/index.php/ASIMTOT

Build The Equations untuk Penanaman Konsep Penyelesaian Persamaan Linier Satu Variabel Bagi Siswa SMP Kelas VII. Prosiding Seminar Nasional Etnomatnesia. Hlm 385-392.

Martini, Nyoman Tiya. (2015). Pengaruh Pemanfaatan Software Matematika dalam Model Problem Based Learning terhadap Pemahaman Konsep Matematika Siswa Kelas X MIA SMA Negeri 4 Singaraja. Skripsi. FKIP Universitas Pendidikan Ganesha Singaraja. Singaraja.

Moyer-Packenham S. Patricia, Ulmer A. Lori, Anderson L. Katie. (2012). Examining Pictorial Models and Virtual Manipulatives for Third-Grade Fraction Instruction. Journal of Interactive Online learning. Vol. 11. No.3. Winter 2012. Hlm. 103-120.

Moyer-Packenham, S. Patricia. (2016). International Perspectives on Teaching and Learning Mathematics with Virtual Manipulatives. USA: Utah State University Logan, UT.

National Council of Teachers of Mathematics. (2000). Principles and Standars for School Mathematics. Reston, VA: NCTM.

Nay, Florianus. (2019). Implementasi Virtual Manipulative Menggunakan Model Problem Based Learning (PBL) untuk
Mengetahui Kemampuan Pemahaman Konsep Matematika Siswa Kelas VII pada Materi Aljabar di SMP Santo Aloysius Turi Yogyakarta. Thesis.

Ujan, Richardus A.B..(2017). Pemahaman Konsep Matematis Siswa dalam Menyelesaikan Masalah Matematika pada Pokok Bahasan Bangun Datar Segi Empat Kelas VII di SMP Budi Mulia Minggir. Skripsi. 